\title{
SPECTROPHOTOMETRIC DETERMINATION OF ACETYLSALICYLIC ACID, PARACETAMOL AND ASCORBIC ACID BY CHEMOMETRIC METHODS
}

\author{
Guzide Ertokus ${ }^{1, *}$, Asli Tugrul ${ }^{1}$
}

https://doi.org/10.23939/chcht12.03.279

\begin{abstract}
Acetylsalicylic acid, paracetamol, and ascorbic acid which are used for the pain reliever and fever reducer were analyzed without any prior reservation by means of spectrophotometry-chemometry. The experimental calibration matrix was designed by measuring the absorbance within the range of $200-400 \mathrm{~nm}$ for 19 samples of acetylsalicylic acid, paracetamol, and ascorbic acid. Absorbance and concentration values were analyzed using Minitab and other chemometric programs to calculate estimated concentrations by PCR and PLSR. In the first step the synthetic mixtures including acetylsalicylic acid, paracetamol, and ascorbic acid were prepared and absorbance values were obtained according to spectrophotometry. In the second step, amounts of acetylsalicylic acid, paracetamol, and ascorbic acid were calculated in effervescent tablet (Afebryl®). Standard deviations were accomplished. This study encouraged us to apply the developed methods for drug analysis. The methods presented in this paper are rapid and do not need any separation process or preliminary treatments for the analysis.
\end{abstract}

Keywords: paracetamol, acetylsalicylic acid, ascorbic acid, PLSR, PCR.

\section{Introduction}

Paracetamol is a medicine with pain reliever and anti-fever effect. When paracetamol is taken orally, it is rapidly absorbed in the gastrointestinal tract. The drug reaches maximum plasma concentrations after 30-60 min of ingestion [1,2]. Acetylsalicylic acid is a pain-killer and anti-inflammatory drug commonly used for minor pain and infestation. There is also blood diluent effect and long-term low dosage is used to protect against heart attack [3]. Vitamin C is not stored by the body and is sweated with urine and sweat because it is among the

\footnotetext{
${ }^{1}$ Department of Chemistry, Faculty of Science \& Art,

Süleyman Demirel University, 32260 Çünür, Isparta, Turkey

guzideertokus@sdu.edu.tr

(c) Ertokus G., Tugrul A., 2018
}

water-soluble vitamins. For this reason, it needs to be taken back every day. Vitamin C plays an important role in the renewal of strong immune system, collagen production, skin, cartilage, tendon, ligament and blood vessels [4].

Chemometric calibration methods are observed to be the best techniques to determinate the amount of each component in the complex mixture. The most accepted chemometric methods in a drug analysis are principal component regression (PCR) and partial least squares regression (PLSR) [5, 6]. A relationship to be established between matrices of chemical data is determinated at chemometric methods [7].

Chemometrics is the science that accords with extracting valuable information from the raw data. PCR and PLSR calibration methods are intended to be full spectrum computational procedures [8].

Partial least squares regression (PLSR-regression) is the most commonly used chemometric multivariate calibration method [9] and for quantitative analysis of spectroscopic data to determine the amount of drug in multicomponent pharmaceutical products [10].

The Minitab 17 program (Inova, Ankara, Turkey) was used for the analysis of all the concentration and absorbance data to do the statistical calculations. Minitab is a statistical analysis software. In addition to statistical research, statistics can be used to learn [11].

The main aim of this work was the determination of acetylsalicylic acid, paracetamol, and ascorbic acid of tablet sample (Afebryl ${ }^{\circledR}$ effervescent tablet) by chemometric methods. The validation of the proposed UV spectroscopic technique has added precision, accuracy, selectivity and brings successful results with principal component regression (PCR) and partial least squares regression (PLSR) - chemometric methods. In this study, PCR and PLSR were successfully performed to simultaneous determination of acetylsalicylic acid, paracetamol, and ascorbic acid in a commercial tablet formulation without any separation method. Mean recoveries and standard deviation of PCR and PLSR were calculated for the validation of the methods. The acquired results were statistically compared with each other. 


\section{Experimental}

\subsection{M aterials}

All materials used were of analytical grade. Stock solutions of $25 \mathrm{mg} / 250 \mathrm{ml}$ of acetylsalicylic acid (Sigma), paracetamol (Sigma) and ascorbic acid (Sigma) were prepared with $0.1 \mathrm{M} \mathrm{HCl}$. A training set and validation set containe the drugs in various proportions, 19 synthetic mixtures (for validation) were made.

Shimadzu UV-1700 PharmaSpec Spectrophotometer connected to an IBM PC with UV Probe Software was used for all measurements and data processing. A pair of $1.0 \mathrm{~cm}$ quartz cuvettes was used for absorbance measurements.

\subsection{Absorbance M easurements}

Absorbance spectra of acetylsalicylic acid, paracetamol, and ascorbic acid were recorded between 200 and $400 \mathrm{~nm}$ with 0.1 step. The calibration matrix, training and validation sets contain three component mixtures at different rates. To calculate concentrations, the concentration sets and analysis of effervescent tablet have been done using PLSR and PCR.

Samples of 5.0 and $35.0 \mathrm{ppm}$ of drugs (alone or in combination) were placed in volumetric flasks $(25 \mathrm{ml})$ and dissolved in $0.1 \mathrm{M} \mathrm{HCl}$. The mixture was shaken for $20 \mathrm{~min}$ and filtered. Dry tight standards were prepared in the same manner as described, except those with the reagents and drug. A training set and validation set contain the drugs in various proportions, i.e. 19 synthetic mixtures (for validation) were prepared and presented in Table 1.

\subsection{Pharmaceutical Preparations}

Afebryl ${ }^{\circledR}$ effervescent tablet produced by Galepharma, containing $300 \mathrm{mg}$ of acetylsalicylic acid, $300 \mathrm{mg}$ of ascorbic acid and $200 \mathrm{mg}$ of paracetamol per tablet were analyzed by the principal component regression (PCR) and partial least squares regression (PLSR) chemometric methods. For this purpose $1 \mathrm{~g}$ of the samples were mechanically mixed with $0.1 \mathrm{M} \mathrm{HCl}$ and transferred into $25 \mathrm{ml}$ bottles. All the techniques were applied to the final solution.

\section{Results and Discussion}

\subsection{Absorption of Acetylsalicylic Acid, Paracetamol, Ascorbic Acid and M ix Solution}

Absorption of acetylsalicylic acid, paracetamol, ascorbic acid and mix solution are all in the visible region of high absorbent substances. Fig. 1 shows the absorbance-wavelength curves. The spectra of acetylsalicylic acid, paracetamol, and ascorbic acid are in the range of $200-400 \mathrm{~nm}$.

Concentration set for acetylsalicylic acid, paracetamol and ascorbic acid

\begin{tabular}{|c|c|c|c|}
\hline \multirow{2}{*}{ No. } & \multicolumn{3}{|c|}{ Concentration, ppm } \\
\cline { 2 - 4 } & Acetylsalicylic acid & Paracetamol & Ascorbic acid \\
\hline 1 & 6 & 7 & 5 \\
\hline 2 & 12 & 7 & 10 \\
\hline 3 & 18 & 7 & 20 \\
\hline 4 & 24 & 7 & 25 \\
\hline 5 & 30 & 7 & 5 \\
\hline 6 & 6 & 14 & 10 \\
\hline 7 & 12 & 14 & 20 \\
\hline 8 & 18 & 14 & 25 \\
\hline 9 & 24 & 14 & 5 \\
\hline 10 & 30 & 14 & 10 \\
\hline 11 & 6 & 21 & 20 \\
\hline 12 & 12 & 21 & 5 \\
\hline 13 & 18 & 21 & 10 \\
\hline 14 & 24 & 21 & 15 \\
\hline 15 & 6 & 28 & 5 \\
\hline 16 & 12 & 28 & 10 \\
\hline 17 & 18 & 28 & \\
\hline 18 & 6 & 35 & 35 \\
\hline 19 & 12 & & \\
\hline & & 35 & \\
\hline
\end{tabular}




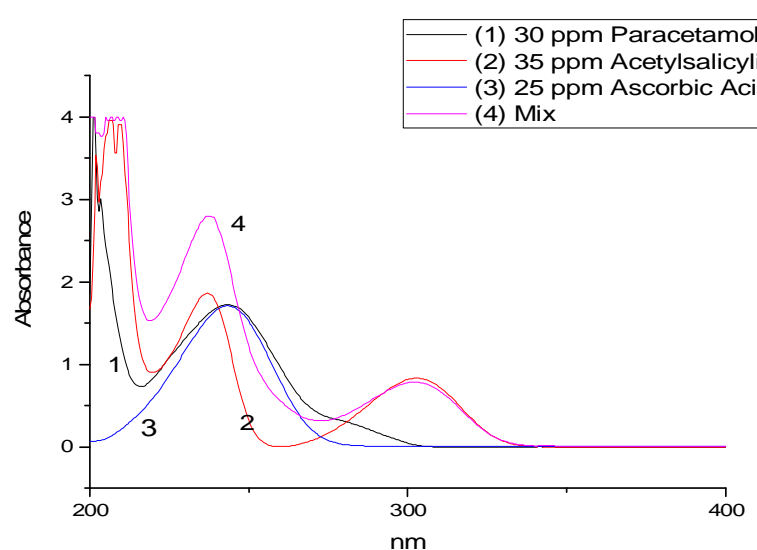

Fig. 1. Original absorption spectra of $30 \mathrm{ppm}$ paracetamol, $35 \mathrm{ppm}$ acetylsalicylic acid

and $25 \mathrm{ppm}$ ascorbic acid and their mixture in $0.1 \mathrm{M} \mathrm{HCl}$

\subsection{Principal Component Regression (PCR) and Partial Least Squares Regression (PLSR)}

The PLSR method and absorption spectra can be used individually or overlapped with multiple simultaneous detections of various linear components. Some statistical parameters were given for validation of calibrations for synthetic mixtures of drugs.

The statistical parameters were found to produce a satisfactory validity for the PLSR and PCR methods. The PLSR and PCR methods have reliable accuracy and higher precision. Judging from the results obtained, the standard deviation values are sufficiently small and the recovery values are sufficiently close to 100 . This shows us that the results obtained are appropriated.

Table 2

\section{Composition of prediction set and recovery results obtained} in synthetic mixtures for PLSR method

\begin{tabular}{|c|c|c|c|c|c|c|c|c|}
\hline \multicolumn{3}{|c|}{ Actual concentration, $\mathrm{ppm}$} & \multicolumn{3}{|c|}{ Prediction concentration, $\mathrm{ppm}$} & \multicolumn{3}{|c|}{ Recovery, $\%$} \\
\hline $\begin{array}{l}\text { Acetyl- } \\
\text { salicylic } \\
\text { acid }\end{array}$ & $\begin{array}{c}\text { Para- } \\
\text { cetamol }\end{array}$ & $\begin{array}{c}\text { Ascorbic } \\
\text { acid }\end{array}$ & $\begin{array}{l}\text { Acetyl- } \\
\text { salicylic } \\
\text { acid }\end{array}$ & $\begin{array}{c}\text { Para- } \\
\text { cetamol }\end{array}$ & $\begin{array}{c}\text { Ascorbic } \\
\text { acid }\end{array}$ & $\begin{array}{l}\text { Acetyl- } \\
\text { salicylic } \\
\text { acid }\end{array}$ & $\begin{array}{c}\text { Para- } \\
\text { cetamol }\end{array}$ & $\begin{array}{c}\text { Ascorbic } \\
\text { acid }\end{array}$ \\
\hline 7 & 6 & 5 & 7.01 & 5.97 & 4.83 & 100.15 & 99.5 & 96.6 \\
\hline 7 & 12 & 10 & 6.82 & 11.51 & 9.85 & 97.43 & 95.92 & 98.5 \\
\hline 7 & 18 & 15 & 6.95 & 17.58 & 14.85 & 99.29 & 97.67 & 99 \\
\hline 7 & 24 & 20 & 7.05 & 24.04 & 20.01 & 100.72 & 100.17 & 100.05 \\
\hline 7 & 30 & 25 & 7.03 & 30.06 & 24.95 & 100.43 & 100.2 & 99.8 \\
\hline 14 & 6 & 5 & 14.05 & 5.93 & 5.01 & 100.36 & 98.84 & 100.2 \\
\hline 14 & 12 & 10 & 14.06 & 11.83 & 9.69 & 100.43 & 98.59 & 96.9 \\
\hline 14 & 18 & 15 & 14 & 17.82 & 14.69 & 100 & 99 & 97.94 \\
\hline 14 & 24 & 20 & 13.53 & 23.62 & 19.68 & 96.65 & 98.42 & 98.4 \\
\hline 14 & 30 & 25 & 13.96 & 29.51 & 24.86 & 99.72 & 98.37 & 99.44 \\
\hline 21 & 6 & 5 & 20.71 & 5.54 & 4.89 & 98.62 & 92.34 & 97.8 \\
\hline 21 & 12 & 10 & 20.63 & 11.52 & 9.65 & 98.24 & 96 & 96.5 \\
\hline 21 & 18 & 15 & 21.01 & 17.82 & 14.51 & 100.05 & 99 & 96.74 \\
\hline 21 & 24 & 20 & 20.84 & 23.83 & 19.8 & 99.24 & 99.30 & 99 \\
\hline 28 & 6 & 5 & 27.73 & 5.84 & 4.89 & 99.04 & 97.34 & 97.8 \\
\hline 28 & 12 & 10 & 27.83 & 11.82 & 9.87 & 99.40 & 98.5 & 98.7 \\
\hline 28 & 18 & 15 & 27.71 & 17.96 & 14.96 & 98.97 & 99.78 & 99.74 \\
\hline 35 & 6 & 5 & 34.85 & 5.74 & 4.85 & 99.58 & 95.67 & 97 \\
\hline \multirow[t]{2}{*}{35} & 12 & 10 & 35.02 & 11.94 & 10.01 & 100.06 & 99.5 & 100.1 \\
\hline & & & & & & $\begin{array}{c}\text { Mean: } 99.37 \\
\text { Standard } \\
\text { deviation: } 1.07\end{array}$ & $\begin{array}{c}\text { Mean: } 98.11 \\
\text { Standard } \\
\text { deviation:1.95 }\end{array}$ & $\begin{array}{c}\text { Mean: } 98.43 \\
\text { Standard } \\
\text { deviation:1. } 27\end{array}$ \\
\hline
\end{tabular}


Table 3

\section{Composition of prediction set and recovery results obtained} in synthetic mixtures for PCR method

\begin{tabular}{|c|c|c|c|c|c|c|c|c|}
\hline \multicolumn{3}{|c|}{ Actual concentration, $\mathrm{ppm}$} & \multicolumn{3}{|c|}{ Prediction concentration, $\mathrm{ppm}$} & \multicolumn{3}{|c|}{ Recovery, \% } \\
\hline $\begin{array}{c}\text { Acetyl- } \\
\text { salicylic acid }\end{array}$ & $\begin{array}{c}\text { Para- } \\
\text { cetamol }\end{array}$ & $\begin{array}{l}\text { Ascorbic } \\
\text { acid }\end{array}$ & $\begin{array}{l}\text { Acetyl- } \\
\text { salicylic } \\
\text { acid }\end{array}$ & $\begin{array}{c}\text { Para- } \\
\text { cetamol }\end{array}$ & $\begin{array}{l}\text { Ascorbic } \\
\text { acid }\end{array}$ & $\begin{array}{l}\text { Acetyl- } \\
\text { salicylic } \\
\text { acid }\end{array}$ & $\begin{array}{c}\text { Para- } \\
\text { cetamol }\end{array}$ & $\begin{array}{l}\text { Ascorbic } \\
\text { acid }\end{array}$ \\
\hline 7 & 6 & 5 & 6.95 & 5.89 & 4.78 & 99.29 & 98.17 & 95.6 \\
\hline 7 & 12 & 10 & 6.87 & 11.82 & 9.98 & 98.15 & 98.5 & 99.8 \\
\hline 7 & 18 & 15 & 6.66 & 17.89 & 14.95 & 95.15 & 99.39 & 99.67 \\
\hline 7 & 24 & 20 & 6.92 & 23.95 & 19.86 & 98.86 & 99.80 & 99.3 \\
\hline 7 & 30 & 25 & 7.01 & 29.85 & 25.01 & 100.15 & 99.5 & 100.04 \\
\hline 14 & 6 & 5 & 13.95 & 6.01 & 5.01 & 99.65 & 100.17 & 100.2 \\
\hline 14 & 12 & 10 & 14.01 & 11.85 & 9.78 & 100.08 & 98.75 & 97.8 \\
\hline 14 & 18 & 15 & 13.85 & 17.56 & 14.56 & 98.93 & 97.56 & 97.07 \\
\hline 14 & 24 & 20 & 13.95 & 23.86 & 19.96 & 99.65 & 99.42 & 99.8 \\
\hline 14 & 30 & 25 & 13.81 & 29.92 & 24.97 & 98.65 & 99.74 & 99.88 \\
\hline 21 & 6 & 5 & 19.8 & 5.85 & 4.96 & 94.29 & 97.5 & 99.2 \\
\hline 21 & 12 & 10 & 21 & 11.95 & 9.87 & 100 & 99.59 & 98.7 \\
\hline 21 & 18 & 15 & 21.06 & 17.95 & 14.62 & 100.29 & 99.73 & 97.47 \\
\hline 21 & 24 & 20 & 20.66 & 23.96 & 19.98 & 98.39 & 99.84 & 99.9 \\
\hline 28 & 6 & 5 & 27.84 & 5.87 & 4.9 & 99.43 & 97.84 & 98 \\
\hline 28 & 12 & 10 & 27.57 & 11.89 & 10.01 & 98.47 & 99.09 & 100.1 \\
\hline 28 & 18 & 15 & 27.51 & 17.92 & 14.98 & 98.25 & 99.56 & 99.87 \\
\hline 35 & 6 & 5 & 34.73 & 5.86 & 4.98 & 99.23 & 97.67 & 99.6 \\
\hline \multirow[t]{2}{*}{35} & 12 & 10 & 35.01 & 11.92 & 9.97 & 100.03 & 99.34 & 99.7 \\
\hline & & & & & & $\begin{array}{c}\text { Mean: } 98.78 \\
\text { Standard } \\
\text { deviation: } 1.59\end{array}$ & $\begin{array}{c}\text { Mean: } 99.00 \\
\text { Standard } \\
\text { deviation: } \\
1.87\end{array}$ & $\begin{array}{c}\text { Mean: } 99.03 \\
\text { Standard } \\
\text { deviation: } \\
1.28\end{array}$ \\
\hline
\end{tabular}

\subsection{V alidation of the $M$ ethod}

For calibration the prediction residual error sum-ofsquares (PRESS) was calculated as:

$$
\text { PRESS }=\sum_{i=1}^{n}\left(C_{i}^{\text {added }}-C_{i}^{\text {found }}\right)^{2}
$$

where $C_{i}^{\text {added }}$ - actual concentration, the added concentration of drug; $C_{i}^{\text {found }}$ - predicted concentration, the calculated concentration of drug.

According to the actual and predicted concentrations of the samples, PRESS values of acetylsalicylic acid, paracetamol, and ascorbic acid were calculated and listed in Table 2.

It is important to emphasize that this is not a correct way to normalize the PRESS values when not all of the data sets contain the same number of samples. But standard error of prediction $(S E P)$ values contain the number of samples. Some statistical parameters determined the effectiveness of the calibration. The $S E P$ was calculated using the following expression:

$$
S E P=\sqrt{\frac{\sum_{i=1}^{n}\left(C_{i}^{\text {added }}-C_{i}^{\text {found }}\right)^{2}}{n-1}}
$$

where $n$ - the total number of synthetic mixtures.

$P R E S S$ and $S E P$ values are close to zero, the degree of accuracy is increasing. The obtained PRESS and SEP values are close to zero for PLSR and PCR methods.

\subsection{Analysis of Pharmaceutical Formulation}

The experimental results of two methods for pharmaceutical formulation are given in Table 5. One can see that the obtained results are very close to each other.

In order to compare the performances of the investigated chemometric techniques according to UV spectrophotometric method for real samples we applied Snedecor's $F$-test [12]. 
Statistical parameter values for calibration step-simultaneous determination of acetylsalicylic acid, paracetamol, and ascorbic acid using PLSR and PCR methods

\begin{tabular}{|c|c|c|c|c|}
\hline \multirow{2}{*}{ Parameter } & \multirow{2}{*}{ Method } & \multicolumn{3}{|c|}{ Compound, ppm } \\
\cline { 3 - 5 } & & Acetylsalicylic acid & Paracetamol & Ascorbic acid \\
\hline \multirow{2}{*}{ PRESS } & PLSR & 0.04 & 0.07 & 0.04 \\
& PCR & 0.11 & 0.02 & 0.02 \\
\hline \multirow{2}{*}{ SEP } & PLSR & 0.05 & 0.07 & 0.05 \\
& PCR & 0.06 & 0.04 & 0.03 \\
\hline
\end{tabular}

Table 5

Determination of acetylsalicylic acid, paracetamol, and ascorbic acid in pharmaceutical formulation using PLSR and PCR methods

\begin{tabular}{|c|c|c|c|c|c|c|}
\hline No & \multicolumn{3}{|c|}{ PLSR } & \multicolumn{2}{c|}{ PCR } \\
\hline & $\begin{array}{c}\text { Acetylsalicylic } \\
\text { acid }\end{array}$ & Paracetamol & Ascorbic acid & $\begin{array}{c}\text { Acetylsalicylic } \\
\text { acid }\end{array}$ & Paracetamol & Ascorbic acid \\
\hline 1 & 0.295 & 0.198 & 0.278 & 0.281 & 0.192 & 0.297 \\
\hline 2 & 0.296 & 0.186 & 0.29 & 0.284 & 0.193 & 0.298 \\
\hline 3 & 0.281 & 0.182 & 0.284 & 0.286 & 0.187 & 0.296 \\
\hline 4 & 0.279 & 0.194 & 0.281 & 0.29 & 0.182 & 0.285 \\
\hline 5 & 0.293 & 0.178 & 0.293 & 0.295 & 0.186 & 0.284 \\
\hline Mean & 0.289 & 0.188 & 0.285 & 0.287 & 0.188 & 0.292 \\
\hline $\begin{array}{c}\text { Standard } \\
\text { deviation }\end{array}$ & 0.0081 & 0.0083 & 0.0062 & 0.0055 & 0.0045 & 0.0069 \\
\hline
\end{tabular}

The method used to compare the differences between the one-way ANOVA test was applied to the actual samples for each food drug. In this study, Snedecor's $F$-values were calculated and compared with the $F$ value. The same computation process was repeated for each drugs. Fig. 2 shows ANOVA results. The experimental (calculated) $F$-values did not exceed the $F$ value in the variance analysis. Among all these methods, it was concluded that there was a meaningful difference. All statistical parameters and numeric values are suitable for simultaneous identification in the actual samples.

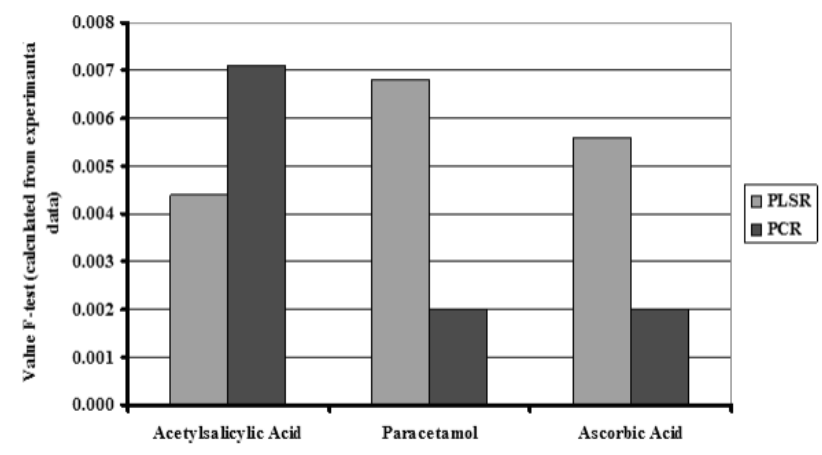

Fig. 2. The results of the one-way ANOVA test accoding to Snedecor's $F$-test

\section{Conclusions}

The partial least squares method and principle component regression successfully applied at the same time were able to identify drugs in synthetic solutions and pharmaceutical formulation. For all values low prediction errors and high correlation coefficients emphasize the high linear relationship between the predicted and actual concentrations. The results obtained with this ternary mixture and some ratios of component concentrations show excellent predictive ability with these methods.

\section{Acknowledgements}

This research work has been supported by research grants from Süleyman Demirel University Scientific Research Project 4757-YL1-16.

\section{References}

[1] Issa Y., Zayed S., Habib I.: Arab. J. Chem., 2011, 4, 259. https://doi.org/10.1016/j.arabjc.2010.06.044 [2] Khoshayand M., Abdollahi H., Shariatpanahi M. et al.: Spectrochim. Acta A, 2008, 70, 491. https://doi.org/10.1016/j.saa.2007.07.033 
[3] Prado T., Cincotto F., Machado S.: Electrochim. Acta, 2017, 233, 105. https://doi.org/10.1016/j.electacta.2017.03.038

[4] Silva T., Aguiar-Oliveira E., Mazalli M. et al.: Food Chem., 2017, 224, 92. https://doi.org/10.1016/j.foodchem.2016.12.052 [5] Dinç E., Baleanu D.: J. Pharmaceut. Biomed., 2002, 30, 715. https://doi.org/10.1016/S0731-7085(02)00359-X

[6] Dinç E., Özdemir A., Baleanu D.: J. Pharmaceut. Biomed., 2005, 37, 569. https://doi.org/10.1016/j.jpba.2004.11.020

[7] Aktaş A., Sarıdağ A.: J. Chromatogr. Sci., 2017, 55, 798. https://doi.org/10.1093/chromsci/bmx039

[8] Darwish H., Elzanfaly E., Saad A. et al.: Spectrochim. Acta A, 2016, 169, 50. https://doi.org/10.1016/j.saa.2016.06.001

[9] Kenneth R.: Chemometrics: A practical Guide. John Wiley \& Sons. Inc., New York 1997.

[10] Glavanovic S., Glavanovic M., Tomisic V.: Spectrochim. Acta A, 2016, 157, 258. https://doi.org/10.1016/j.saa.2015.12.020

[11] http://www.causeweb.org/repository/Minitab/Minitab.pdf (30.05.2017).

[12] Ayoub B.: Spectrochim. Acta A, 2016, 168, 122. https://doi.org/10.1016/j.saa.2016.06.010

Received: August 03, 2017 /Revised: September 18, 2017 / Accepted: December 12, 2017
СПЕКТРОФОТОМЕТРИЧНЕ ВИЗНАЧЕННЯ АЦЕТИЛСАЛІЦИЛОВОЇ КИСЛОТИ, ПАРАЦЕТАМОЛУ ТА АСКОРБІНОВОӤ КИСЛОТИ ХЕМОМЕТРИЧНИМИ МЕТОДАМИ

Анотація. Проведено спектрофотометрично-хемометричний аналіз без будь-яких попередніх застережень ацетилсаліцилової кислоти, парацетамолу та аскорбінової кислоти, які використовують як анаболіки та препарати для зниження температури. Розроблено експериментальну калібрувальну матриию внаслідок вимірювання поглинальної здатності в діапазоні 200-400 нм для 19 зразків ацетилсалічилової кислоти, парацетамолу та аскорбінової кислоти. Проаналізовано значення поглинальної здатності та концентрації, використовуючи Мinitab та інші хемометричні програми для розрахунку концентраиій за допомогою методів PCR i PLSR. На першому етапі готували синтетичні суміші з ащетилсаліцилової кислоти, паращетамолу та аскорбінової кислоти, i отримали значення поглинальноі здатності відповідно до спектрофотометрії. На другому етапі кількість ацетилсалічилової кислоти, парацетамолу та аскорбінової кислоти розраховувалася в шипучій таблетиі (Afebryl®). Розраховані стандартні відхилення, які дали можливість запропонувати розроблені методи для аналізу препаратів. Показано, щзо методи є швидкими $і$ не потребують будь-якого процесу розділення або попереднього оброблення для проведення аналізу.

Ключові слова: парацетамол, ацетилсаліцилова кислота, аскорбінова кислота, PLSR, PCR. 